\title{
Pendampingan pelaksanaan dan pembiasaan adaptasi kehidupan baru bagi masyarakat
}

\author{
Susilawati*, Sadakata Sinulingga, Riana Sari Puspita, Masayu Farah Diba, Puji Rizki \\ Suryani
}

Program Studi Pendidikan Dokter, Fakultas Kedokteran, Universitas Sriwijaya, E-mail: susilwt78@gmail.com

\begin{abstract}
Abstrak
Dunia dikejutkan dengan merebaknya virus baru yaitu corona virus jenis baru (SARS-CoV-2) pada tahun 2020 dan penyakitnya disebut Corona Virus Disease 19 (Covod-19). Virus ini pertama kali ditemukan di Wuhan, Tiongkok pada akhir Desember 2019 dan menyebar ke seluruh dunia. Adaptasi Kebiasaan Baru adalah sebuah upaya masyarakat untuk beradaptasi dengan lingkungan, dalam bentuk perubahan perilaku diri menjadi lebih disiplin, menjaga kebersihan, dan menaati peraturan protokol kesehatan. Kegiatan pengabdian masyarakat yang dilakukan bertujuan memberikanpenyuluhan secara langsung kepada masyarakat (maksimal 10 orang) Tegal Binangun Lorong Talang Petai RT. 30 Kelurahan Plaju Darat tentang tanda dan gejala, cara penularan, pencegahan COVID-19 dan adaptasi kehidupan baru. Selain penyuluhan, dilakukan pendampingan praktek cuci tangan yang baik dan benar, cara memakai masker yang benar, pembuangan dan pencucian masker kain, pembuatan desinfektan yang akan diajarkan secara langsung kepada masyarakat. Hasil posttest menunjukkan peningkatan nilai rata-rata yang cukup signifikan dibanding saat pretest. Warga yasng sebelumnya hanya mengetahui penggunaan cara memakai masker di era new normal ini, menjadi mengetahui cara memakai masker dengan benar, cara melepas masker, mencuci masker, mencuci tangan yang baik dan benar serta membuat desinfektan. Perlu dilakukan kegiatan pengabdian yang berkesinambungan dengan topik-topik penyakit yang berbeda juga pengabdian berupa pelayanan pemeriksaan dan pengobatan gratis kepada masyarakat sehingga selain mendapatkan pengetahuan yang baru juga dapat menikmati langsung pelayanan kesehatan.
\end{abstract}

Kata Kunci: COVID-19, Protokol Kesehatan, Masker

\begin{abstract}
Assistance in The Implementation and Adaptation of New Habits for The Community. The world was shocked by the outbreak of a new type of coronavirus (SARS-CoV-2) in 2020 and the disease is called Corona Virus Disease 19 (Covid-19). This was first discovered in Wuhan, China in late December 2019 and has spread all over the world. Adaptation of New Habits is an effort of the community to adapt to the environment, in the form of changes in selfbehavior to be more disciplined, maintain cleanliness, and adhere to health protocol regulations. Community service activities provided direct counseling to the community (maximum 10 people) in Tegal Binangun Lorong Talang Petai RT. 30 Plaju Darat about signs and symptoms, ways of transmission, prevention of COVID-19 and adaptation of new life. In addition to educate the community, counseling, assistance of good and correct hand washing, how to wear the correct mask, disposal and washing of cloth masks, making disinfectants will be taught directly to the community. The posttest results showed a significant increase in average value compared to the pretest. The residents who previously only knew how to wear masks in this new normal era, became aware of how to wear masks correctly, how to remove masks, wash masks, wash hands properly and make disinfectants. It is necessary to hold continuous service activities carried out
\end{abstract}


with different topics of disease as well as devotion in the form of free health services to the community so that in addition to gain new information can also obtain direct health services.

\section{PENDAHULUAN}

Pada awal tahun 2020, dunia dikejutkan dengan merebaknya virus baru yaitu corona virus jenis baru (SARS-CoV-2) dan penyakitnya disebut Corona Virus Disease 19 (Covod-19). Virus ini pertama kali ditemukan di Wuhan, Tiongkok pada akhir Desember 2019 (Data WHO, 1 Maret 2020; PDPI, 2019). Terhitung sampai dengan 20 September 2020, jumlah kasus Covid19 di dunia sebanyak 30,9 juta orang (kompas.com, 2020). ${ }^{1}$

Corona virus merupakan virus RNA strain tunggal positif, berkapsul dan tidak bersegmen. Coronavirus tergolong ordo Nidovirales, keluarga Coronaviridae. Struktur corona virus membentuk struktur seperti kubus dengan protein $S$ berlokasi di permukaan virus. Protein $S$ atau spike protein merupakan salah satu protein antigen utama virus dan merupakan struktur utama untuk penulisan gen. Protein S ini berperan dalam penempelan dan masuknya virus kedalam sel host (interaksi protein S dengan reseptornya di sel inang) (Wang, 2020). Infeksi COVID-19 dapat menimbulkan gejala ringan, sedang atau berat. Gejala klinis utama yang muncul yaitu demam (suhu $>38^{\circ} \mathrm{C}$ ), batuk dan kesulitan bernapas. Selain itu dapat disertai dengan napas berat, fatigue, mialgia, gejala gastrointestinal seperti diare dan gejala saluran napas lain. Kebanyakan pasien memiliki prognosis baik, namun sebagian kecil dapat menyebabkan kondisi kritis bahkan kematian (PDPI, 2020). ${ }^{2}$

Tindakan pencegahan jauh lebih baik dari pada pengobatan. Kepatuhan semua orang terhadap tindakan pencegahan memegang peran penting dalam memutus mata rantai penyebaran Covid-19. Pandemi COVID-19 yang sedang terjadi membawa adanya tatanan kehidupan normal baru sebagai respon realistis terhadap eksistensi Covid-19. Bila hal ini tidak dilakukan, maka akan terjadi risiko penularan. Pada masa pandemi masyarakat Indonesia diharuskan hidup dengan tatanan hidup baru, yang dapat 'berdamai' dengan Covid-19. Adapun yang dimaksud dengan New Normal adalah suatu tindakan atau perilaku 
yang dilakukan oleh masyarakat dan semua institusi yang ada di wilayah tersebut untuk melakukan pola harian atau pola kerja atau pola hidup baru yang berbeda dengan sebelumnya. Bila hal ini tidak dilakukan, akan terjadi risiko penularan. Tujuan dari New Normal adalah agar masyarakat tetap produktif dan aman dari Covid-19 di masa pandemik. Selanjutnya agar New Normal lebih mudah diinternalisasikan oleh masyarakat maka "New Normal” dinarasikan menjadi “Adaptasi Kebiasaan Baru”. Maksud dari Adaptasi Kebiasaan Baru adalah agar kita bisa bekerja, belajar dan beraktivitas dengan produktif di era Pandemi Covid-19. (Kemenkes RI, 2020). ${ }^{3}$

Masih banyak masyarakat yang belum memahami adaptasi kehidupan baru dan pentingnya melaksanakan tantanan kehidupan normal dalam pencegahan penyebaran Covid-19. Masih ditemukan tempat keramaian masyarakat tidak menggunakan masker dan tidak menjaga jarak. Kebiasaan mencuci tanganpun masih belum dilaksanakan oleh seluruh masyarakat. Ketersediaan handsanitizer di fasilitas umum terutama di daerah pedesaan masih belum mencukupi. Hal ini bisa jadi disebabkan karena kurang memahami tantanan kehidupan normal baru atau juga karena masalah ekonomi, sementara pandemi ini belum juga berakhir dan tidak satu orangpun yang bisa memprediksi kapan pandemi ini berakhir.

Kegiatan pengabdian pada masyarakat ditujukan untuk memberikan penyuluhan secara langsung kepada perangkat desa (maksimal 10 orang) tentang:

1. Tanda dan gejala Covid-19,

2. Cara penularan Covid-19

3. Pencegahan Covid-19

4. Adaptasi Kehidupan Baru

Selain penyuluhan, pada kegiatan pengabdian ini juga akan dilakukan pendampingan praktek cuci tangan yang baik dan benar, cara memakai masker yang benar, pembuangan dan pencucian masker kain serta pembuatan desinfektan yang akan diajarkan secara langsung kepada perangkat desa maksimal 5 orang dengan protokol pencegahan Covid-19, dan akan dibuat video, kemudian video ini akan disebar oleh ketua RT ke WA 
grup masyarakat ataupun secara japri. Selain itu akan juga dilakukan pembagian masker kain, handsanitizer dan desinfektan kepada warga. Dengan kegiatan ini diharapkan dapat meningkatkan pengetahuan masyarakat khususnya warga di Tegal Binangun lorong Talang Petai tentang bahaya penyakit Covid-19, tindakan pencegahan terhadap penyakit Covid-19, serta masyarakat makin memiliki kesadaran untuk melaksanakan adaptasi kebiasaan baru sehingga penyebaran corona virus dapat ditekan dan masyarakat tetap produktif dalam melaksanakan kegiatannya.

\section{TINJAUAN PUSTAKA}

Jumlah kasus infeksi COVID-19 terkonfirmasi mencapai 571.678 kasus hingga 28 Maret 2020. Awalnya kasus terbanyak terdapat di Cina, namun saat ini kasus terbanyak terdapat di Italia dengan 86.498 kasus, diikut oleh Amerika dengan 85.228 kasus dan Cina 82.230 kasus. Virus ini telah menyebar hingga ke 199 negara. Kematian akibat virus ini telah mencapai 26.494 kasus. Tingkat kematian akibat penyakit ini mencapai 4-5\% dengan kematian terbanyak terjadi pada kelompok usia di atas 65 tahun. Indonesia melaporkan kasus pertama pada 2 Maret 2020, yang diduga tertular dari orang asing yang berkunjung ke Indonesia. Kasus di Indonesia pun terus bertambah, hingga tanggal 29 Maret 2020 telah terdapat 1.115 kasus dengan kematian mencapai 102 jiwa. Tingkat kematian Indonesia 9\%, termasuk angka kematian tertinggi (WHO, 2019). ${ }^{4}$

Patogenesis Covid-19 belum diketahui seutuhnya. Penelitian lain menunjukkan protein (S) memfasilitasi masuknya virus Corona ke dalam sel target. Proses ini bergantung pada pengikatan protein $S$ ke reseptor selular dan priming protein $S$ ke protease selular. Penelitian hingga saat ini menunjukkan kemungkinan proses masuknya COVID-19 ke dalam sel mirip dengan SARS. Hal ini didasarkan pada kesamaan struktur (76\%) antara SARS dan Covid-19. Sehingga diperkirakan virus ini menarget Angiotensin Converting Enzyme 2 (ACE2) sebagai reseptor masuk dan menggunakan serine protease TMPRSS2 untuk priming $S$ protein, meskipun hal ini masih membutuhkan penelitian lebih lanjut (Handayani et.al, 2020). ${ }^{5}$ Coronavirus hanya bisa memperbanyak diri melalui sel host-nya. 
Virus tidak bisa hidup tanpa sel host. Berikut siklus dari Coronavirus setelah menemukan sel host sesuai tropismenya. Pertama, penempelan dan masuk virus ke sel host diperantarai oleh Protein S yang ada dipermukaan virus. Protein S penentu utama dalam menginfeksi spesies host-nya serta penentu tropisnya (Wang, 2020). ${ }^{6}$ Pada studi SARS-CoV protein S berikatan dengan reseptor di sel host yaitu enzim ACE-2 (angiotensin-converting enzyme 2). ACE-2 dapat ditemukan pada mukosa oral dan nasal, nasofaring, paru, lambung, usus halus, usus besar, kulit, timus, sumsum tulang, limpa, hati, ginjal, otak, sel epitel alveolar paru, sel enterosit usus halus, sel endotel arteri vena, dan sel otot polos. Setelah berhasil masuk selanjutnya translasi replikasi gen dari RNA genom virus. Selanjutnya replikasi dan transkripsi sintesis virus RNA melalui translasi dan perakitan dari kompleks replikasi virus. Tahap selanjutnya adalah perakitan dan rilis virus (Maier, 2015) ${ }^{7}$ Setelah terjadi transmisi, virus masuk ke saluran napas atas kemudian bereplikasi di sel epitel saluran napas atas (melakukan siklus hidupnya). Setelah itu menyebar ke saluran napas bawah. Pada infeksi akut terjadi peluruhan virus dari saluran napas dan virus dapat berlanjut meluruh beberapa waktu di sel gastrointestinal setelah penyembuhan. Masa inkubasi virus sampai muncul penyakit sekitar 3-7 hari (PDPI, 2020). ${ }^{2}$

Infeksi COVID-19 dapat menimbulkan gejala ringan, sedang atau berat. Gejala klinis utama yang muncul yaitu demam (suhu $>38^{\circ} \mathrm{C}$ ), batuk dan kesulitan bernapas. Selain itu dapat disertai dengan sesak memberat, fatigue, mialgia, gejala gastrointestinal seperti diare dan gejala saluran napas lain. Setengah dari pasien timbul sesak dalam satu minggu. Pada kasus berat perburukan secara cepat dan progresif, seperti ARDS, syok septik, asidosis metabolik yang sulit dikoreksi dan perdarahan atau disfungsi sistem koagulasi dalam beberapa hari. Pada beberapa pasien, gejala yang muncul ringan, bahkan tidak disertai dengan demam. Kebanyakan pasien memiliki prognosis baik, dengan sebagian kecil dalam kondisi kritis bahkan meninggal. 
Pencegahan sangat diperlukan dalam menurunkan angka kejadian COVID-19. Ada beberapa cara/kebiasaan yang harus dilakukan dalam memutus mata rantai penularan Covid-19 yaitu:

1. Mencuci tangan dengan sabun air dan sabun mengalir minimal 20 detik

2. Menutup mulut dan hidung dengan masker

3. Jaga jarak 1-2 meter

4. Hindari memegang berbagai barang

5. Hindari berada dalam kerumunan

6. Hindari berkumpul di tempat-tempat umum

7. Memasak dan memanaskan makanan secara menyeluruh

8. Segera mencuci tangan pakai sabun setelah bersentuhan langsung dengan binatang, seperti mengelus atau bermain, memberi makan,dan membersihkan kandangnya

9. Membersihkan tangan dengan cairan hand sanitizer berbasis alkohol, ethanol $60 \%$, atau $70 \%$ isopropanol alcohol

10. Hindari menyentuh area wajah, terutama mata, mulut, dan hidung

11. Bersihkan permukaan benda/perlengkapan yang sering disentuh secara reguler dengan disinfektan,seperti gagang pintu, handphone, komputer, dan lain-lain.

12. Hindari bersentuhan dengan orang lain

13. Hindari melakukan perjalanan

14. Segera berkonsultasi dengan dokter/petugas kesehatan ketika timbul gejala sakit $(\mathrm{BKKBN}, 2020){ }^{8}$

Berbagai sektor di Indonesia saat ini terus menyiapkan Panduan Adaptasi Kebiasaan Baru agar dapat diaktifkan kembali dengan tetap mempertimbangkan kondisi setiap wilayah. Peran serta masyarakat untuk disiplin dalam protokol kesehatan menjadi kunci utama. Adaptasi Kebiasaan Baru adalah sebuah upaya masyarakat untuk beradaptasi dengan lingkungan, dalam bentuk perubahan perilaku diri menjadi lebih disiplin, menjaga 
kebersihan, dan menaati peraturan protokol kesehatan. Agar masyarakat tetap produktif sekaligus tetap aman dari Covid-19.

Pemerintah Indonesia telah mengambil langkah-langkah yang bersifat komprehensif dalam upaya preventif melalui physical distancing, social distancing, pengadaan alat pelindung diri (APD), sampai pada pembatasan sosial berskala besar (PSBB). Paska pemberlakuan PSBB dengan kondisi pandemi Covid-19 yang masih berlangsung, diperlukan upaya mitigasi dan kesiapan tempat kerja seoptimal mungkin agar masyarakat pekerja dapat beradaptasi melalui perubahan pola hidup pada situasi Covid-19 (New Normal). Berkaitan dengan hal ini, penerapan panduan dari Pemerintah diharapkan dapat meminimalisir risiko dan dampak pandemi Covid-19 pada tempat kerja, terlebih-lebih perkantoran dan industri, yang mana di kedua tempat ini terdapat potensi penularan Covid-19 akibat berkumpulnya banyak orang. Panduan dari Pemerintah tersebut, antara lain panduan berdasarkan Keputusan Menteri Kesehatan Republik Indonesia Nomor Hk.01.07/Menkes/328/2020, merupakan panduan pencegahan dan pengendalian COVID-19 di tempat kerja perkantoran dan industri, yang disusun secara umum untuk membantu dunia kerja dalam meningkatkan peran dan kewaspadaannya untuk mengantisipasi penularan Covid-19 di lingkungan kerja, serta memberikan perlindungan seoptimal mungkin bagi kesehatan pekerja.

Promosi Kesehatan merupakan proses perubahan perilaku/proses belajar secara terencana pada diri individu, kelompok atau masyarakat dalam meningkatkan kemampuan (pengetahuan-sikap dan ketrampilan) untuk mencapai derajat hidup sehat yang optimal. Promosi kesehatan juga berperan sebagai pilar utama pembangunan kesehatan yang menempatkan masyarakat sebagai subjek perubahan dapat dioptimalkan dalam upaya meningkatkan kesiapan masyarakat dalam menghadapi tatanan new normal (Susilawati, 2016). ${ }^{9}$

Kesiapan masyarakat menghadapi new normal tidak hanya terlihat dari aspek sosial, melainkan juga terlihat secara fisik dan mental. Fisik sehat yang senantiasa menerapkan 
PHBS dan protokol kesehatan serta mental yang tetap tenang dan terhindar dari gangguan kecemasan selama pandemi Covid-19 menjadi cerminan kesiapan masyarakat dalam menghadapi kehidupan new normal mendatang. Tentunya selain kesiapan masyarakat, penerapan new normal juga memerlukan kesiapan pemerintah daerah dalam segala aspek, termasuk ketersediaan fasilitas dan sumber daya kesehatan.

Dukungan sumber daya dan sumber dana untuk memfasilitasi berbagai sarana kesehatan sangat diperlukan oleh Pemerintah untuk mengantisipasi berbagai kemungkinan yang terjadi akibat pandemi. Meskipun pemerintah tidak bisa melakukan estimasi secara tepat jumlah penderita yang akan terpapar Covid-19, namun untuk mengatasi ledakan jumlah kasus warga masyarakat yang terpapar Covid-19, Pemerintah membentuk Gugus Tugas Covid-19 berdasarkan Kepres 7 Tahun 2020 tentang Gugus Tugas Percepatan Penanganan Corona Virus Disease 2019 (Kemenkes RI, 2020). ${ }^{10}$ Untuk mengurangi beban dan dampak bekelanjutan pandemi global Covid-19, Pemerintah dan masyarakat harus bersinergi dalam membangun sistem kesehatan nasional yang kuat melalui dukungan dana berupa iuran sebagaimana sudah dirumuskan dan ditetapkan.

\section{METODE}

Khalayak sasaran dari kegiatan ini adalah warga lorong Talang Petai RT. 30 dan perangkat desa (maksimal 10 orang) untuk kegiatan pendampingan praktik cara mencuci tangan yang benar, pemakaian masker yang benar, pencucian masker kain, pebuatan desinfectan.

Kegiatan pengabdian masyarakat ini melibatkan 4 orang dosen dari Fakultas Kedokteran Universitas Sriwijaya. Kegiatan ini juga melibatkan 2 orang mahasiswa dari Program Studi Pendidikan Dokter Fakultas Kedokteran dengan tujuan agar ajang ini dapat dijadikan sebagai sarana pembelajaran bagi mahasiswa bagaimana terjun ke masyarakat secara langsung dan mengenali masalah kesehatan dimasyarakat serta upaya pencegahannya. 
Metode kegiatan yang dilakukan adalah sebagai berikut:

a. Penyuluhan, dilakukan dengan ceramah dan diskusi dengan perangkat desa (maksimal 10 orang, dengan menerapkan protokol kesehatan pencegahan Covid-19) tentang gejala, pencegahan Covid-19 dan Adaptasi Kebiasaan Baru.

b. Pendampingan cara mencuci tangan yang benar, cara menggunakan masker yang baik, cara membuang masker disposibel dan pencucian masker kain serta pembuatan desinfectan.

c. Pembuatan video pendampingan poin b untuk disebar keseluruh warga melalui wa grup RT.

d. Pemantauan, untuk mengetahui keberhasilan dari kegiatan yang telah dilaksanakan oleh dosen dan mahasiswa

Rancangan evaluasi terdiri dari dua bagian yaitu terhadap masyarakat dan terhadap mahasiswa. Rancangan evaluasi ini diperlukan untuk mengetahui tingkat keberhasilan dari kegiatan.

Tahap 1, Analisis potensi lokasi pengabdian (dilakukan saat penyusunan proposal), melalui tanya jawab dan pretest berupa 10 pertanyaan dengan tokoh masyarakat dan beberapa anggota masyarakat tentang gejala tanda covid-19, tindakan pencegahan, dan adaptasi kehidupan baru.

Tahap 2, pada saat kegiatan berlangsung. Evaluasi ini diperlukan untuk mengetahui pengetahuan masyarakat tentang gejala dan tanda Covid-19, tindakan pencegahan, dan adaptasi kehidupan baru.

Tahap 3, pada saat akhir kegiatan. Setelah masyarakat diberikan penyuluhan tentang gejala tanda Covid-19, tindakan pencegahan, dan adaptasi kehidupan baru. Mengetahui keberhasilan kegiatan dengan memberikan pertanyaan posttest setelah dilakukan kegiatan penyuluhan dan pendampingan praktik cuci tangan yang benar, pemakaian dan pencucian masker kain serta pembuatan desinfektan . 
Indikator pencapaian tujuan dan tolak ukur yang digunakan untuk mengetahui keberhasilan dari kegiatan ini adalah: Jika perangkat desa paham tentang gejala tanda Covid-19, tindakan pencegahan, dan adaptasi kehidupan baru melalui sesi tanya jawab, bisa melakukan sendiri cuci tangan yang benar, cara memakai dan mencuci masker dengan benar serta memahami adaptasi kebiasaan baru. Seluruh warga mendapatkan video pendampingan praktik sekaligus mampu melakukan sendiri dan mulai memahami serta terbiasa dengan adaptasi kehidupan baru. Selain warga mampu mempraktikan setelah di beri penyuluhan, hasil post-test juga di bandingkan dengan hasil pre-test dari 10 pertanyaan dan 8 responden, apakah ada perbaikan jawaban setelah diberikan penyuluhan. Dan pertanyaan mana yang sebelumnya responden dari sebelum penyuluhan, belum mengetahui sama sekali kebenarannya.

\section{HASIL DAN PEMBAHASAN}

Kegiatan pengabdian kepada masyarakat dengan judul: "Pendampingan Pelaksanaan dan Pembiasaan Adaptasi Kehidupan Baru Bagi Masyarakat" telah dilaksanakan di di Daerah Tegal Binangun RT 30 RW 05 desa Talang Petai, Kelurahan Plaju Darat, Kecamatan Plaju pada hari Minggu tanggal 8 November 2020. Kegiatan ini diikuti oleh perangkat desa saja karena situasi pandemi yaitu berjumlah 10 orang sebagai perwakilan yang mengikuti penyuluhan dan kegiatan pendampingan dengan protokol pencegahan Covid-19. Pelaksanaan pengabdian ini berjalan dengan lancar.

Kegiatan dimulai dengan memberikan pretest dalam 10 pertanyaan yang telah disiapkan. Ada 8 orang responden yang mengikuti test, yang dimana dari 10 pertanyaan banyak responden yang belum mengetahui kebenarannya. Dari pertanyaan pertama mengenai penyebab penyakit covid, semua responden mengetahui penyebabnya. Pertanyaan kedua, mengenai gejala penyakit covid, semua koresponden dapat menjawab dengan benar. Pertanyaan ketiga, mengenai tindakan yang dilakukan dalam usaha pencegahan penyebaran,, hanya 25\% responden yang mampu menjawab dengan benar. 
Pertanyaan keempat mengenai jenis masker yang diketahui, 62,5\% responden hanya mengetahui jenis masker kain satu lapis. Pertanyaan kelima mengenai, kapan menggunakan masker, 75\% responden menjawab hanya ketika keluar rumah. Pertanyaan keenam mengenai cara mencuci tangan yang baik, 100\% responden belum mengetahui caranya. Pertanyaan ketujuh mengenai menyebutkan langkah-langkah cuci tangan yang baik, dikarenakan belum mengetahui caranya jadi responden tidak dapat menyebutkan langkah-langkahnya. Pertanyaan kedelepan mengenai cara mencuci masker kain yang telah digunakan, 100\% responden menjawab mencuci seperti biasa dicampur dengan pakaian kotor lainnya. Pertanyaan kesembilan mengenai jumlah masker yang digunakan dalam satu hari, hanya 25\% responden menggunakan 2 masker dalam sehari, 75\% nya satu masker dalam satu hari. Pertanyaan terakhir mengenai apakah masih mengahidiri acara pesta selama pandemi, hanya 25\% yang tidak pernah pergi ke pesta selama pandemi.

Setelah dibagikan pretest, dilanjutkan dengan penyuluhan kepada peserta pengabdian tentang apa itu Covid-19, tanda dan gejala Covid-19, cara penularan Covid-19, pencegahan Covid-19 dan Adaptasi Kehidupan Baru. Edukasi tentang tantanan kehidupan baru yang harus dilaksanakan dalam usaha pencegahan penyebaran Covid-19 namun tetap bisa melaksanakan aktivitas sehingga tetap produktif.

Selanjutnya pada kegiatan pengabdian ini juga dilakukan pengenalan kepada para kader dan pemuka masyarakat tentang macam-macam masker, cara membuang masker disposibel dan mencuci ulang masker kain, desinfectan serta handsanitizer. Juga mengenalkan tatanan kehidupan baru yang harus dilakukan dalam melaksanakan aktivitas sehari-hari. Selanjutnya dilakukan juga pendampingan dan praktik pemakaian masker bedah dan masker kain yang benar, pembuatan desinfektan dengan memanfaatkan pemutih pakaian, serta cuci tangan yang baik dan benar

Pada kegiatan penyuluhan dapat terlihat peserta yang hadir memiliki pertanyaan terkait materi penyuluhan maupun masalah kesehatan yang dialami dirinya sendiri maupun keluarga. Pertanyaan pun beragam mulai dari gejala klinis Covid-19, cara 
pencegahan dan tindakan yang mesti dilakukan jika ada kasus disekitar mereka. Walaupun pada daerah RT 30 Tegal Binangun belum ada kasus yang terinfeksi Covid, namun peserta penyuluhan terlihat antusias dalam menyimak penyuluhan yang dilakukan.

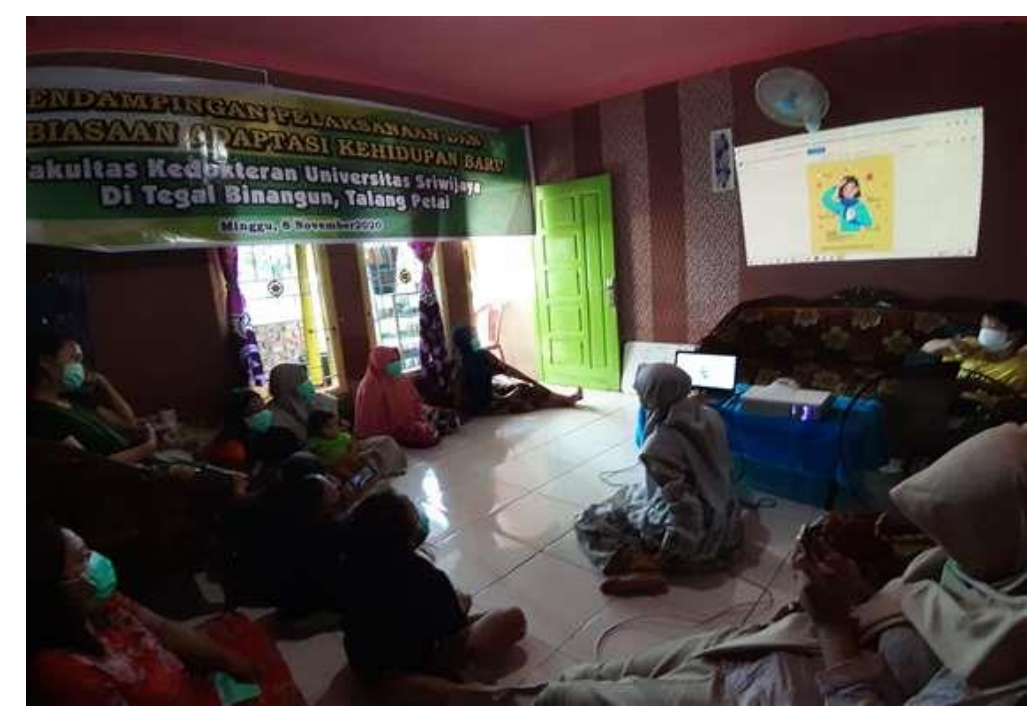

Gambar 1. Peserta Pengabdian (Pemuka Masyarakat dan Kader) menyimak penyuluhan tentang Covid-19.

Selain kegiatan penyuluhan, pengabdian inipun melaksanakan tutorial cara memakai masker yang benar, cara memakai ulang masker kain, cara membuang masker bedah, serta cara mencuci tangan yang harus menggunakan sabun dan air mengalir sehingga yakin tangan yang dicuci bena-benar bersih. Peserta yang hadir di latih cara memakai masker bedah dan masker kain, serta diberitahu dalam kondisi apa saja yang harus menggunakan masker. Setelah diberi penjelasan cara memakai masker, seluruh peserta dibagi masker dan diminta langsung untuk mempraktekkan memakai masker. Hasilnya semua peserta dapat menggunakan masker dengan benar. Selain itu peserta juga diberi penjelasan tentang pentingnya melakukan desinfektan terhadap permukaan bendabenda yang sering disentuh oleh orang banyak. Desinfektan dapat dibuat sendiri dengan memanfaatkan pemutih pakaian yang sering dipakai sehari-hari. Kegiatan pengabdian ini juga melakukan bimbingan cara mencuci tangan yang baik dan benar serta menyampaikan 
bahwa poin penting adalah harus sering mencuci tangan sebelum dan setelah memegang benda-benda. Tahap awal, kami menyampaikan secara teori tentang cara mencuci tangan yang baik dan benar, kemudian mempraktikkan langkah-langkah cuci tangan, peserta diminta untuk menyimak dan menghafal langkah-langkah tersebut. Peserta yang sebelumnya belum mengetahui langkah nya setelah di beri penjelasan dan praktek langsung, semua peserta dapat melakukan 6 langkah mencuci tangan dengan baik dan benar sesuai anjuran WHO. Akhir dari kegiatan pengabdian ini adalah penyerahan bantuan masker, desinfektan, handsanitizer dan 5 paket tempat untuk menampung air untuk mencuci tangan kepada ketua RT 30 untuk dibagikan ke seluruh warga RT 30 desa talang Petai Tegal Binangun.

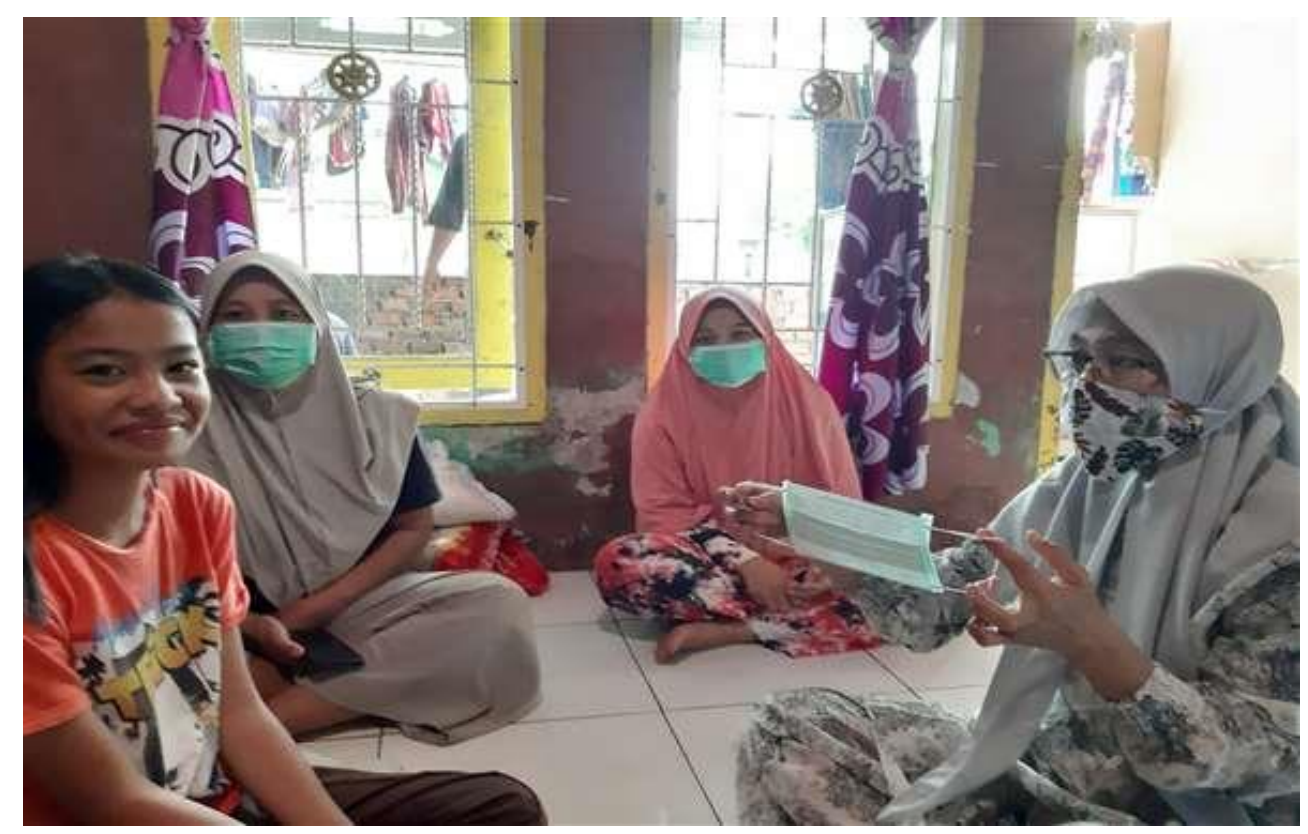

Gambar 2. Melatih memakai masker bedah 


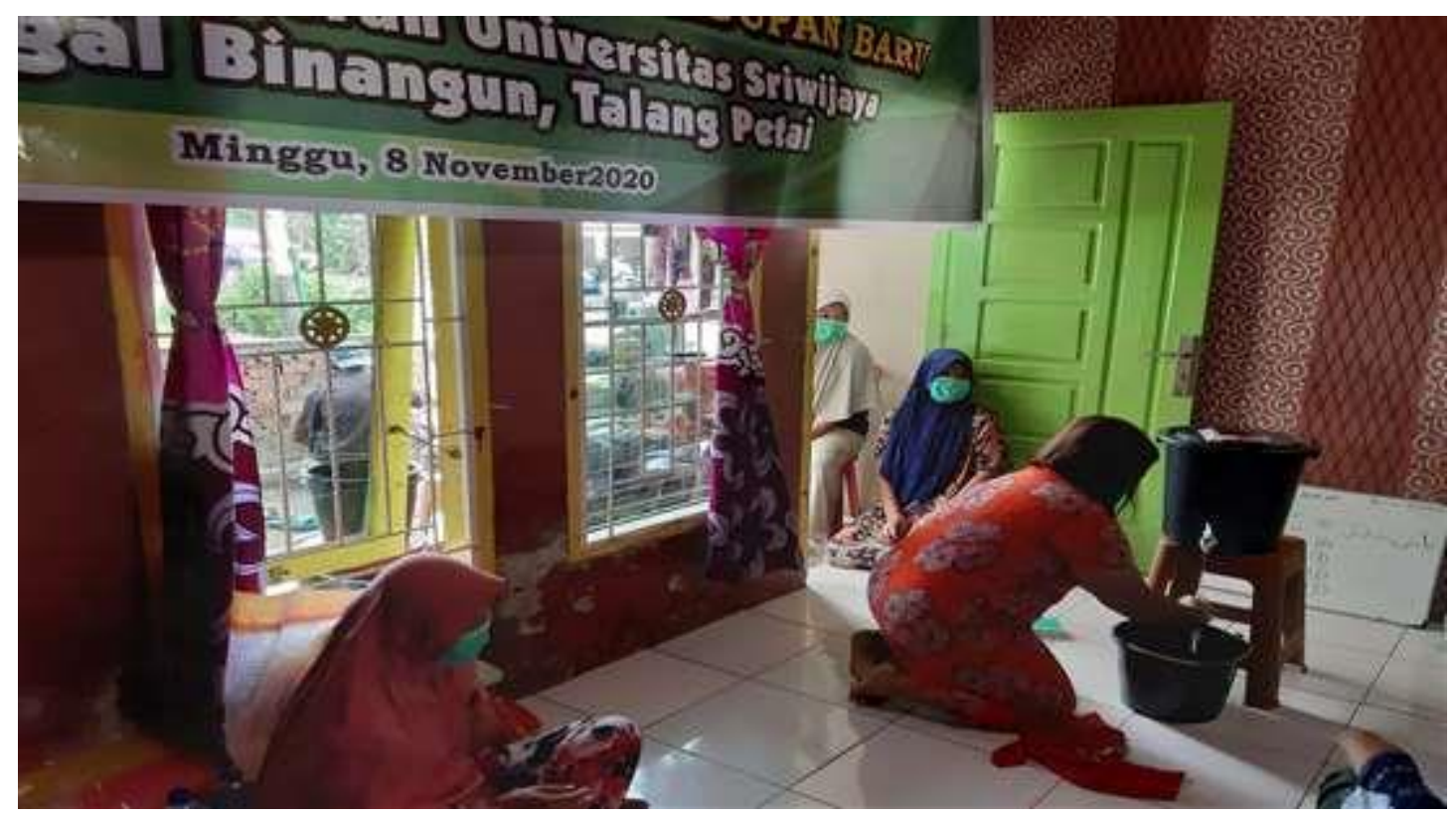

Gambar 3. Peserta Mempraktikan Langkah- langkah Cuci Tangan

Setelah dilakukan penyuluhan dan praktik cara menggunakan masker dan langkahlangkah mencuci tangan dengan benar, dilukukan posttest untuk mengetahui tingkat keberhasilan kegiatan. Dari 10 pertanyaan yang telah dilakukan dengan jenis pertanyaan yang sama dengan pretest, peserta mampu menjawab semua dengan benar. Hasil pretest dan postest setelah di analisis, ada peningkatan skor menjawab pertanyaan yang benar, peserta mampu menyebutkan dan mempraktikkan cuci tangan yang baik dan benar didepan penyuluh dan Mampu mempraktikan cara memakai masker yang baik dan benar didepan penyuluh. Dari poin-point yang telah di daparkan menujukkan kegiatan ini berhasil dilakukan, yang dimana awalnya peserta belum mengetahui kebenarannya menjadi mengetahui semuanya.

\section{SIMPULAN}

Kegiatan pengabdian pada masyarakat dengan judul "Pendampingan Pelaksanaan dan Pembiasaan Adaptasi Kehidupan Baru pada Masyarakat" di Daerah Tegal Binangun RT 30 RW 05 desa Talang Petai, Kelurahan Plaju Darat, Kecamatan Plaju telah menambah 
wawasan dan pengetahuan masyarakat dan kader kesehatan tentang penyakit Covid-19, terutama gejala klinis, cara penularan serta tindakan pencegahan yang harus dilakukan. Selain itu juga masyarakat menjadi paham tentang adaptasi kehidupan baru agar tetap bisa beraktifitas dalam memenuhi kebutuhan hidup dengan kebiasaan pencegahan penularan Covid-19 melalui penggunaan masker, menjaga jarak dan sering melakukan cuci tangan sebelum dan setelah menyentuh benda-benda. Hal ini sesuai dengan hasil posttest responden yang semua jawabannya benar dibandingkan pretest yang banyak responden yang belum mengetahui kebenerannya. Masih banyak masyarakat yang belum mengetahui langkah-langkah mencuci tangan dan cara pencegahan penyakit covid-19 dengan benar, perlu dilakukan penyuluhan kembali ke masyarakat lainnya agar masyarakat terhindar dari penyakit covid-19. Dan juga perlu dilakukan kegiatan pengabdian yang berkesinambungan dengan topik-topik penyakit yang berbeda juga pengabdian berupa pelayanan pemeriksaan dan pengobatan gratis kepada masyarakat sehingga selain mendapatkan pengetahuan yang baru juga dapat menikmati langsung pelayanan kesehatan.

\section{Ucapan Terima Kasih}

Penulis mengucapkan banyak terimakasih sebesar-besarnya kepada semua pihak yang telah membantu sehingga pengabdian ini dapat terlaksana dengan baik, terutama kepada Rektor Universitas Sriwijaya, Ketua Pusat Pelayanan dan Pengembangan Lembaga Penelitian dan Pengabdian (PPP-LPPM) UNSRI, Dekan FK UNSRI, Ketua RT 30 RW 05 desa Talang Petai, Kelurahan Plaju Darat, Kecamatan Plaju Serta masyarakat dan juga kepada DIPA Fakultas Kedokteran Universitas Sriwijaya yang telah mendanai pelaksaan kegiatan pengabdian kepada masyarakat ini. Sesuai dengan Surat Perjanjian Pelaksanaan Kegiatan

Pengabdian Kepada Masyarakat Fakultas kedokteran Universitas Sriwijaya. Nomor: 86/011/UN9.14/PLP-PPM/PL/X/2020. 


\section{Referensi}

1. Kompas.com. Update Covid-19 di Dunia 20 September: 30,9 Juta Infeksi | 10 Negara dengan Kasus Terbanyak. www.kompas.com.

2. PDPI. PANDUAN PRAKTIK KLINIK ( PPK ) Perhimpunan Dokter Paru Indonesia. 2020.

3. Kesehatan K. Pedoman Pencegahan dan Pengendalian Corona Virus deases (Covid19). Kementrian Kesehat. 2020;5:178.

4. who. WHO Director-General's remarks at the media briefing on 2019-nCov on 11 February 2020. www.who.int.

5. Handayani, D., Hadi, D. R., Isbaniah, F., Burhan, E., Agustin H. Penyakit Virus Corona 2019. J Respirologi Indones. 2020;40(2):119-129.

6. Wang Z, Qiang W, Ke H. A Handbook of 2019-nCoV Pneumonia Control and Prevention. Hubei Sci Technol Press. 2020:1-108.

7. Maier HJ, Bickerton E, Britton P. Coronaviruses: Methods and protocols. Coronaviruses Methods Protoc. 2015;1282(1):1-282. doi:10.1007/978-1-4939-2438-7

8. Badan Kependudukan dan Keluarga Nasional. Adaptasi Terhadap Kebiasaan Baru : Panduan Kerja Sehat, Aman, dan Produktif Selama Masa Pandemi Covid 19. Bkkn. 2020;(July):1-49.

9. Susilawati D. PROMOSI KESEHATAN. 1st ed. kemenkes; 2016.

10. Kementerian Kesehatan. Direktorat Promosi Kesehatan Pemberdayaan Masyarakat,. http://promkes.kemkes.go.id. 